\title{
ANALISIS KESALAHAN PENERAPAN KATA BAKU DAN TANDA BACA DALAM MENULIS KEMBALI ISI CERITA FABEL
}

\author{
Itsna Ayu Rahmawati ${ }^{1}$, Mudzanatun ${ }^{2}$, Ibnu Fatkhu Royana ${ }^{3}$ \\ ${ }^{1,2,3}$ Fakultas IImu Pendidikan \\ Universitas PGRI Semarang \\ Semarang, Indonesia \\ e-mail: itsnaayurahmawati@gmail.com ${ }^{1}$, mudzana8@gmail.com² ${ }^{2}$, \\ royanaif@gmail.com ${ }^{3}$
}

\begin{abstract}
Abstrak
Penelitian ini dilatarbelakangi banyak siswa yang menulis tidak menggunakan kata baku dan tanda baca yang tepat. Dalam hasil tulisan siswa banyak ditemukan kesalahan penerapan kata baku dan tanda baca. Hal tersebut menyebabkan hasil tulisan siswa sulit dibaca dan dipahami, selain itu juga dapat menimbulkan makna ganda. Penelitian ini bertujuan untuk mengetahui bentuk kesalahan kata baku dan tanda baca dalam menulis kembali isi cerita fabel subtema 1 manusia dan lingkungan. Jenis penelitian ini adalah penelitian kualitatif deskriptif. Subyek penelitian adalah siswa kelas V SD Negeri Pandean Lamper 04 Semarang. Prosedur pengumpulan data yang digunakan adalah hasil tulisan siswa, angket, dan wawancara. Berdasarkan hasil penelitian, banyak ditemukan kesalahan penerapan kata baku dan tanda baca dalam hasil tulisan siswa. Kesalahan penerapan kata baku berjumlah 233 kata. Kesalahan penerapan tanda baca berjumlah 180 kesalahan. Hal tersebut sesuai dengan hasil angket yang diperoleh bahwa siswa jarang menerapkan kata baku dan tanda baca di sekolah, di rumah, dan dalam kehidupan sehari-hari. Selain itu juga sesuai dengan hasil wawancara guru bahwa siswa menulis tidak menggunakan kata baku dan tanda baca yang tepat.
\end{abstract}

Kata-kata kunci : Kesalahan, Penerapan, Kata Baku, dan Tanda Baca

\begin{abstract}
This research is motivated by many students who write not using standard words and proper punctuation. In the results of many students' writing found errors in the application of standard words and punctuation. This causes the results of student writing difficult to read and understand, but it can also lead to other meanings. This study aims to determine the form of standard word errors and punctuation in rewriting the contents of the fable sub-story 1 human and the environment. This type of research is descriptive qualitative research. The subjects of the research were the fifth grade students of Pandean Lamper 04 Semarang Elementary School. The data collection procedures used were the results of student writing, questionnaires, and interviews. Based on the research results, there were many errors found in the application of standard words and punctuation in students' writing results. Incorrect application of standard words totals 233 words. There were 180 errors in applying punctuation. This is consistent with the results of the questionnaire obtained that, students rarely apply standard words and punctuation in school, at home, and in everyday life. It is also in accordance with the results of the teacher's interview that student write not using standard words and proper punction.
\end{abstract}

Keywords: Errors, Application, Standard Words, and Punctuation 


\section{Pendahuluan}

Bahasa adalah alat komunikasi yang digunakan oleh setiap individu dalam kehidupan sehari-hari. Bahasa juga dikatakan sebagai satuan ujaran yang dihasilkan oleh alat ucap manusia sebagai lambang bunyi yang bersifat arbitrer dan memiliki satuan arti yang lengkap (Dalman, 2018:1). Puji Santosa, dkk (2011:1.3) mengemukakan bahwa bahasa adalah alat komunikasi antara anggota masyarakat berupa lambang bunyi ujaran yang dihasilkan oleh alat ucap manusia. Sedangkan menurut Kusumaningsih (2013:14) bahasa adalah sistem lambanglambang berupa seperangkat bunyi yang bersifat arbriter dan tidak dapat diramalkan. Menurut Chaer (2011:2) fungsi bahasa yang utama adalah sebagai alat untuk bekerjasama atau berkomunikasi di dalam kehidupan manusia bermasyarakat. Dengan menggunakan bahasa mempermudahkan manusia untuk berkomunikasi dan melakukan aktivitas sehari-hari. Negara Indonesia memiliki banyak provinsi dan setiap provinsi memiliki bahasa daerah masing-masing. Sehingga, diperlukan bahasa persatuan yaitu bahasa Indonesia agar warga negara Indonesia dapat bersatu, mudah berkomunikasi, dan satu pemahaman dalam berkomunikasi maupun dalam pemikiran. Bahasa Indonesia sangat penting sehingga perlu diterapkan sejak dini salah satunya melalui pendidikan. Pendidikan adalah usaha sadar dan terencana untuk mewujudkan suasana belajar dan proses pembelajaran agar peserta didik secara aktif mengembangkan potensi dirinya untuk memiliki kekuatan spiritual keagamaan, pengendalian diri, kepribadian, kecerdasan, akhlak mulia, serta keterampilan yang diperlukan dirinya, masyarakat, bangsa dan negara (Undang-Undang Nomor 20 Tahun 2003). Dalam pendidikan, tentu ada kurikulum yang digunakan. Kurikulum yang sekarang diberlakukan yaitu kurikulum 2013.

Pada kurikulum 2006 mata pelajaran bahasa Indonesia lebih mengedepankan pada keterampilan berbahasa (dan bersastra), sedangkan dalam kurikulum 2013, pembelajaran bahasa Indonesia digunakan sebagai sarana untuk mengembangkan kemampuan dan keterampilan menalar. Selain itu dalam kurikulum 2013 bahasa digunakan sebagai penghela ilmu pengetahuan dan pembelajaran berbasis teks. Bahasa Indonesia dalam kurikulum 2013 disajikan menggunakan pendekatan berbasis teks. Teks dapat berwujud teks tertulis maupun teks lisan. Teks merupakan ungkapan pikiran manusia yang lengkap di dalamnya memiliki situasi dan konteks. Dengan kata lain, belajar bahasa Indonesia tidak sekedar memakai bahasa Indonesia sebagai alat komunikasi, tetapi perlu juga mengetahui makna atau bagaimana memilih kata yang tepat sesuai tatanan budaya dan masyarakat pemakainya (Agusrida, 2019).

Keterampilan berbahasa ada empat yaitu keterampilan menyimak, keterampilan berbicara, keterampilan membaca, dan keterampilan menulis. Menurut Resmini dan Juanda (2007:116) menulis adalah suatu keterampilan berbahasa yang digunakan sebagai alat komunikasi secara tidak langsung antar penulis dan pembaca dalam ragam bahasa tertulis. Dalman (2018:4) berpendapat menulis yaitu proses penyampaian pikiran, angan-angan, perasaan dalam bentuk lambang/tanda/tulisan yang bermakna. Sedangkan Santosa dkk (2011:6.14) mengemukakan menulis merupakan kegiatan yang dilakukan seseorang untuk menghasilkan sebuah tulisan.

Menulis merupakan suatu proses yang kemampuan, pelaksanaan dan hasilnya diperoleh secara bertahap. Artinya untuk menghasilkan tulisan yang baik umumnya orang melakukannya berkali-kali. Sebagai suatu keterampilan berbahasa, menulis merupakan kegiatan yang kompleks karena penulis dituntut untuk dapat menyusun dan mengorganisasikan isi tulisan serta menuangkannya dalam ragam tulis (Dalman: 2018:2).

Menurut Dalman (2018:13) menulis memiliki tujuan dan manfaat. Ditinjau dari sudut kepentingan pengarang, menulis memiliki enam tujuan yaitu:

1. Tujuan Penugasan

Pada umunya para pelajar, menulis sebuah karangan dengan tujuan untuk memenuhi tugas yang diberikan oleh guru atau sebuah lembaga. Bentuk tulisan ini biasanya berupa makalah, laporan, ataupun karangan bebas. 


\section{Tujuan Estetis}

Para sastrawan pada umumnya menulis dengan tujuan untuk menciptakan sebuah keindahan (estetis) dalam sebuah puisi, cerpen, maupun novel.

\section{Tujuan Penerangan}

Surat kabar maupun majalah merupakan salah satu media yang berisi tulisan dengan tujuan penerangan. Tujuan utama penulis membuat tulisan adalah untuk memberi informasi kepada pembaca.

4. Tujuan Pernyataan Diri

Bentuk tulisan pernyataan diri misalnya surat perjanjian maupun surat pernyataan. Jadi, penulisan surat, baik surat pernyataan maupun surat perjanjian seperti ini merupakan tulisan yang bertujuan untuk pernyataan diri.

5. Tujuan Kreatif

Menulis sebenarnya selalu berhubungan dengan proses kreatif, terutama dalam menulis karya sastra, baik itu berbentuk puisi maupun prosa.

6. Tujuan Konsumtif

Ada kalanya sebuah tulisan diselesaikan untuk dijual dan dikonsumsi oleh para pembaca. Dalam hal ini, penulis lebih mementingkan kepuasan pada diri pembaca. Penulis lebih berorientasi pada bisnis.

Sedangkan manfaat menulis yang dapat dipetik dalam kehidupan ini, di antaranya adalah (1) peningkatan kecerdasan, (2) pengembangan daya inisiatif dan kreativitas, (3) penumbuhan keberanian, dan (4) pendorongan kemauan dan kemampuan mengumpulkan informasi.

Menulis harus memperhatikan aturan penulisan agar mudah dibaca dan dipahami maksud tulisan tersebut. Menulis yang baik adalah menulis yang sesuai dengan aturan yang berlaku seperti menulis menggunakan kata baku dan tanda baca yang benar. Kata baku yaitu kata yang cara penulisannya ataupun pengucapannya sesuai dengan kaidah-kaidah yang telah dibakukan (Kosasih dan Hermawan, 2012:83). Menurut KBBI (2017:257) kata baku adalah kata yang berlaku yang ditetapkan berdasarkan kesepakatan, standar. Sedangkan Ernawati dalam Fita dan Isnawati (2016:22) mengemukakan kata baku adalah ragam bahasa yang cara pengucapan maupun penulisannya sesuai dengan kaidah-kaidah standar.

Tanda baca merupakan tanda-tanda yang dipakai dalam sistem ejaan terutama dalam bentuk tulisan (KBBI, 2017:141). Sedangkan Sugono dalam Rajab (2017:9) berpendapat tanda baca adalah tanda-tanda dalam tulisan misalnya tanda titik, tanda koma, dll. Menurut Chaer (2017:71) tanda baca adalah tanda-tanda yang digunakan di dalam bahasa tulis agar kalimatkalimat yang kita tulis dapat dipahami orang persis seperti yang kita maksudkan.

Suyitno dan Ngatmini (2018:198) menyebutan penulisan tanda baca terdiri dari: (1) tanda titik yang terdiri dari 8 tata cara penulisan, (2) tanda koma yang terdiri dari 14 tata cara penulisan, (3) tanda titik koma yang terdiri dari 2 tata cara penulisan, (4) tanda titik dua yang terdiri dari 5 tata cara penulisan, (5) tanda hubung yang terdiri dari 7 tata cara penulisan, (6) tanda pisah yang terdiri dari 3 tata cara penulisan, (7) tanda elipsis yang terdiri dari 2 tata cara penulisan, (8) tanda tanya yang terdiri dari 2 tata cara penulisan, (9) tanda seru yang terdiri dari 1 tata cara penulisan, (10) tanda kurung yang terdiri dari 4 tata cara penulisan, (11) tanda kurung siku yang terdiri dari 2 tata cara penulisan, (12) tanda petik yang terdiri dari 5 tata cara penulisan, (13) tanda petik tunggal yang terdiri dari 2 tata cara penulisan, (14) tanda garis miring yang terdiri dari 2 tata cara penulisan, dan (15) tanda penyingkat atau apostrof yang terdiri dari 1 tata cara penulisan.

Menulis kembali cerita adalah kemampuan atau kesanggupan siswa untuk menulis kembali gambaran isi cerita yang telah dibacanya dari awal hingga akhir cerita ke sebuah tulisan (Amin dalam Bintari Wahyu Setianingrum 2013:12). Menurut Hardjono dalam Dina 
Nurmalisa (2010) menulis kembali adalah suatu kegiatan untuk menuliskan pokok-pokok pikiran yang terkandung dalam bacaan.

Dalam menulis kembali terdapat beberapa langkah yang harus diperhatikan yaitu:

1. Membaca cerita dan membuat simpulan isi cerita

Setelah membaca cerita tulislah judul, tokoh utama cerita, watak, dan pesan yang terkandung dalam cerita. Kemudian menulis simpulan isi cerita yang telah dibaca dengan bahasa yang mudah dipahami.

2. Menentukan pokok-pokok isi cerita yang dibaca

Menentukan pokok-pokok isi cerita dapat dilakukan dengan menganalisis bagian-bagian penting dari cerita tersebut atau dengan cara menentukan ide-ide pokok cerita kemudian menuliskan ide-ide pokok tersebut.

3. Menulis kembali isi cerita yang telah dibaca dengan bahasa sendiri dengan pilihan kata yang tepat.

Setelah menulis pokok-pokok isi cerita, kemudian dikembangkan pokok-pokok dari isi cerita tersebut dengan pilihan kata yang tepat dalam kalimat yang jelas dan efektif menjadi kerangka cerita. Lengkapi dan rangkai kerangka cerita menjadi cerita yang utuh dan perbaiki cerita yang telah utuh tersebut dengan memperbaiki ejaan, tanda baca, dan tata bahasanya.

Fabel adalah salah satu bentuk cerita (tradisional) yang menampilkan binatang sebagai tokoh cerita. Binatang-binatang tersebut dapat berpikir dan berinteraksi layaknya komunitas manusia, juga dengan permasalahan hidup layaknya manusia (Nurgiyantoro, 2010:190). Resmini dan Juanda (2007:181) menjelaskan fabel merupakan dongeng yang mengangkat kehidupan binatang atau unsur alam lain sebagai bahan ceritanya. Dalam fabel, binatang atau unsur alam lain itu mampu bermasyarakat dan berkomunikasi (berbicara) layaknya sebagai manusia. Sedangkan Rosdiana, dkk (2008:6.8) mengemukakan fabel adalah cerita yang menampilkan hewan-hewan sebagai tokoh-tokohnya.

Menurut Resmini dan Juanda (2007:181) karakteristik fabel adalah berkisah tentang binatang atau unsur alam lain yang mampu berbicara (berkomunikasi) layaknya manusia, berisifat simbolis, bersifat didaktis dan moralitas, ringkas dan sederhana. Nurgiyantoro (2010:222) menjelaskan unsur-unsur fabel sebagai berikut:

1. Tokoh

Tokoh adalah pelaku yang dikisahkan perjalanan hidupnya dalam cerita sebagai pelaku maupun penderita berbagai peristiwa yang diceritakan.

2. Alur cerita.

Alur merupakan rangkaian peristiwa yang terjadi berdasarkan hubungan sebab akibat.

3. Latar

Latar merujuk pada tempat, yaitu lokasi di mana cerita itu terjadi, waktu, kapan cerita itu terjadi, dan lingkungan sosial-budaya, keadaan kehidupan, bermasyarakat tempat tokoh dan peristiwa terjadi.

4. Tema

Tema merupakan dasar pengembangan sebuah cerita.

5. Moral

Moral dapat dipahami sebagai sesuatu yang ingin disampaikan kepada pembaca. Sesuatu itu selalu berkaitan dengan berbagai hal yang berkonotasi positif, bermanfaat bagi kehidupan, dan mendidik. 


\section{Sudut pandang}

Sudut pandang adalah sebuah cara, strategi, atau siasat yang secara sengaja dipilih pengarang untuk mengungkapkan cerita dan gagasannya.

Berdasarkan hasil wawancara dengan guru kelas V SD Negeri Pandean Lamper 04 Semarang, Ibu Wahyuni Tugiarti, S.Pd menjelaskan bahwa dalam proses pembelajaran tentu ada kegiatan menulis. Saat kegiatan menulis tentu siswa mengalami kesulitan karena tidak semua siswa mudah memahami tulisan. Hasil tulisan siswa sangat beragam karena ada yang suka menulis ada yang tidak suka menulis. Hasil tulisan siswa juga sering terdapat kesalahan baik penulisan kata, kalimat maupun kesesuain isinya. Saat melakukan kegiatan menulis siswa masih bingung dan membutuhkan waktu yang lama.

Dalam menulis kata baku dan tanda baca masih banyak siswa yang mengalami kesulitan dan kesalahan. Menurut Ibu Wahyuni, tidak hanya siswa saja yang kesulitan tetapi guru juga masih kesulitan dalam menulis kata baku. Hal tersebut disebabkan karena dalam kehidupan sehari-hari kita sering terpengaruh oleh kata-kata gaul. Contohnya saat berkomunikasi sehari-hari siswa menggunakan kata-kata gaul yang akhirnya diingat dan menjadi kebiasaan. Siswa terbiasa mendengar kata-kata gaul lalu menggunakannya saat berkomunikasi maupun saat menulis. Sementara itu siswa kurang menggunakan kata baku dan kurang mendengar kata baku dalam kehidupan sehari-hari. Lingkungan siswa mempengaruhi kebiasaan dan pemikiran siswa.

Selain itu penerapan tanda baca juga belum dipahami oleh siswa. Masih banyak siswa yang belum paham penggunaan tanda baca saat menulis. Sebagai contoh, saat menulis kebanyakan siswa tidak menggunakan tanda baca titik diakhir kalimat. Kemudian hasil tulisan tersebut dibaca, siswa dan guru tidak memahami tulisan tersebut. Penerapan tanda baca yang tidak sesuai akan mempersulit memahami makna dari tulisan, selain itu juga dapat menimbulkan makna lainnya.

Penelitian yang mengkaji tentang analisis kesalahan penerapan kata baku dan tanda baca yang relevan dengan penelitian ini adalah penelitian yang dilakukan oleh Siti Khodijah tahun 2017 dengan judul "Analisis Kesalahan Huruf Kapital dan Tanda Baca pada Paragraf Deskriptif Siswa Kelas V MI Nurul Islam Grogol Depok". Hasil penelitian yang dilakukan Siti Khodijah yaitu berdasarkan 30 tulisan siswa yang telah dianalisis, pada tanda baca kesalahan terbesar yaitu pada penghilangan tanda titik pada akhir kalimat yang bukan pertanyaan/seruan dengan presentase $39,13 \%$.

Berdasarkan masalah yang telah diuraikan di atas, peneliti berminat untuk melakukan penelitian dengan judul "Analisis Kesalahan Penerapan Kata Baku dan Tanda Baca Dalam Menulis Kembali Isi Cerita Fabel Subtema 1 Manusia dan Lingkungan Kelas V SD Negeri Pandean Lamper 04 Semarang". Penelitian ini bertujuan untuk mengetahui bentuk kesalahan kata baku dan tanda baca dalam menulis kembali isi cerita fabel subtema 1 manusia dan lingkungan kelas V SD Negeri Pandean Lamper 04 Semarang.

\section{Metode}

Pendekatan yang digunakan adalah penelitian kualitatif deskriptif. Sugiyono (2016:15) menjelaskan penelitian kualitatif adalah metode penelitian yang berlandaskan pada filsafat postpositivisme, digunakan untuk meneliti pada kondisi obyek yang alamiah, (sebagai lawannya adalah eksperimen) dimana peneliti adalah sebagai instrumen kunci, pengambilan sampel sumber data dilakukan secara purposive dan snowbaal, teknik pengumpulan dengan triangulasi (gabungan), analisis data bersifat induktif/kualitatif, dan hasil penelitian kualitatif lebih menekankan makna daripada generalisasi. Penelitian kualitatif deskriptif berarti data yang terkumpul berbentuk kata-kata atau gambar, sehingga tidak menekankan pada angka. 
1. Setting Penelitian

Penelitian ini dilakukan di SD Negeri Pandean Lamper 04 Semarang. Subyek dalam penelitian ini adalah siswa kelas V SD Negeri Pandean Lamper 04 Semarang.

\section{Data dan Sumber Data}

Data penelitian ini adalah lembar wawancara, lembar angket, dan dokumentasi hasil tulisan siswa dalam menulis kembali isi cerita fabel subtema 1 manusia dan lingkungan. Sumber data dalam penelitian yaitu siswa dan guru kelas V SD Negeri Pandean lamper 04 Semarang.

\section{Prosedur Pengumpulan Data}

Prosedur pengumpulan data menggunakan angket, wawancara, dan hasil tulisan siswa. Dalam penelitian kualitatif instrumennya adalah orang atau human instrument, yaitu peneliti itu sendiri (Sugiyono, 2016:15). Selain itu instrumen yang digunakan dalam penelitian ini adalah kartu data. Kartu data digunakan untuk mencatat dan mengidentifikasi kesalahan kata baku dan tanda baca pada tulisan siswa dalam menulis kembali isi cerita fabel subtema 1 manusia dan lingkungan.

\section{Keabsahan Data}

Menurut Sugiyono (2016:368) uji kredibilitas data terdiri dari perpanjangan pengamatan, peningkatan ketekunan, triangulasi, diskusi dengan teman, analisis kasus negatif, member check. Penelitian ini menggunakan triangulasi teknik yaitu dengan mengecek dan menguraikan hasil wawancara, hasil angket, dan hasil tulisan siswa.

5. Metode Analisis Data

Aktivitas dalam analisis data yaitu data reduction, data display, dan conclusion drawing/verification.

a. Data Reduction (Reduksi Data)

Mereduksi data berarti merangkum, memilih hal-hal yang pokok, memfokuskan pada halhal yang penting, dicari tema dan polanya dan membuang yang tidak perlu.

b. Data Display (Penyajian Data)

Dalam penelitian kualitatif, penyajian data bisa dilakukan dalam bentuk uraian singkat, bagan, hubungan antar kategori, flowchart dan sejenisnya.

c. Conclusion Drawing/Verification

Kesimpulan awal yang dikemukakan masih bersifat sementara, dan akan berubah bila tidak ditemukan bukti-bukti yang kuat yang mendukung pada tahap pengumpulan data berikutnya.

6. Tahapan Penelitian

Menurut Moleong (2002:85) terdiri dari tahap pralapangan, tahap pekerjaan lapangan, dan tahap analisis data.

a. Tahap Pralapangan terdiri dari menyusun rancangan penelitian, memilih lapangan penelitian, mengurus perizinan, menjajaki dan menilai keadaan lapangan, memilih dan memanfaatkan informan, menyiapkan perlengkapan penelitian, persoalan etika penelitian.

b. Tahap Pekerjaan Lapangan terdiri dari memahami latar penelitian dan persiapan diri, memasuki lapangan, berperan serta sambil mengumpulkan data.

c. Tahap Analisis Data. Dalam tahap analisis data, peneliti melakukan analisis hasil wawancara dengan guru kelas V SD Negeri Pandean Lamper 04, hasil angket yang sudah diisi siswa, dan hasil tulisan siswa. Kemudian peneliti menuliskan bagaimana bentuk kesalahan penerapan kata baku dan tanda baca dalam menulis kembali isi cerita fabel subtema 1 manusia dan lingkungan. 


\section{Hasil dan Pembahasan}

Penelitian ini dilaksanakan di SD Negeri Pandean Lamper 04 Semarang yang beralamat di Jalan Banteng Utara VI, Pandean Lamper, Gayamsari, Kota Semarang. Di dalam SD Negeri Pandean Lamper terdapat taman kanak-kanak, masjid, dan gedung pertemuan. Setiap waktu sholat dhuhur siswa sholat berjamaah. Selain itu SD Negeri Pandean Lamper 04 terletak di dalam lorong yang jauh dari jalan raya sehingga suasana di sekolah nyaman, tenang, dan asri.

Jenis penelitian yang digunakan dalam penelitian ini yaitu penelitian kualitatif dengan data yang diperoleh melalui hasil tulisan siswa, angket, dan wawancara. Hasil tulisan siswa digunakan untuk mengetahui bentuk kesalahan penerapan kata baku dan tanda baca. Angket digunakan untuk mengetahui pengalaman dan pengetahuan siswa dalam menerapkan kata baku dan tanda baca. Wawancara dilakukan dengan guru kelas V SD Negeri Pandean Lamper 04 Semarang untuk mengetahui pemahaman siswa menulis menerapkan kata baku dan tanda baca.

Berdasarkan hasil tulisan siswa dalam menulis kembali isi cerita fabel subtema 1 manusia dan lingkungan ditemukan banyak kesalahan penerapan kata baku dan tanda baca. Kesalahan penerapan kata baku dalam hasil tulisan siswa berjumlah 233 kata, sedangkan kesalahan penerapan tanda baca dalam hasil tulisan siswa berjumlah 180 kesalahan. Kesalahan penerapan tanda baca terdiri dari: (a) kesalahan penerapan tanda titik berjumlah 78 kesalahan, (b) kesalahan penerapan tanda koma berjumlah 41 kesalahan, (c) kesalahan penerapan tanda petik berjumlah 48 kesalahan, (d) kesalahan penerapan tanda hubung berjumlah 6 kesalahan, dan (e) kesalahan tanda tanya berjumlah 7 kesalahan. Berikut ini hasil rekapitulasi jumlah kesalahan penerapan kata baku dan tanda baca dalam menulis kembali isi cerita fabel.

Banyaknya kesalahan yang ditemukan dalam hasil tulisan siswa menunjukkan bahwa siswa belum memahami dan menerapkan kata baku dan tanda baca saat menulis. Hal tersebut sesuai dengan hasil angket yang telah diisi oleh siswa kelas V SD Negeri Pandean Lamper 04. Berikut ini hasil angket penerapakan kata baku dan tanda baca di sekolah, di rumah, dan dalam kehidupan sehari-hari.

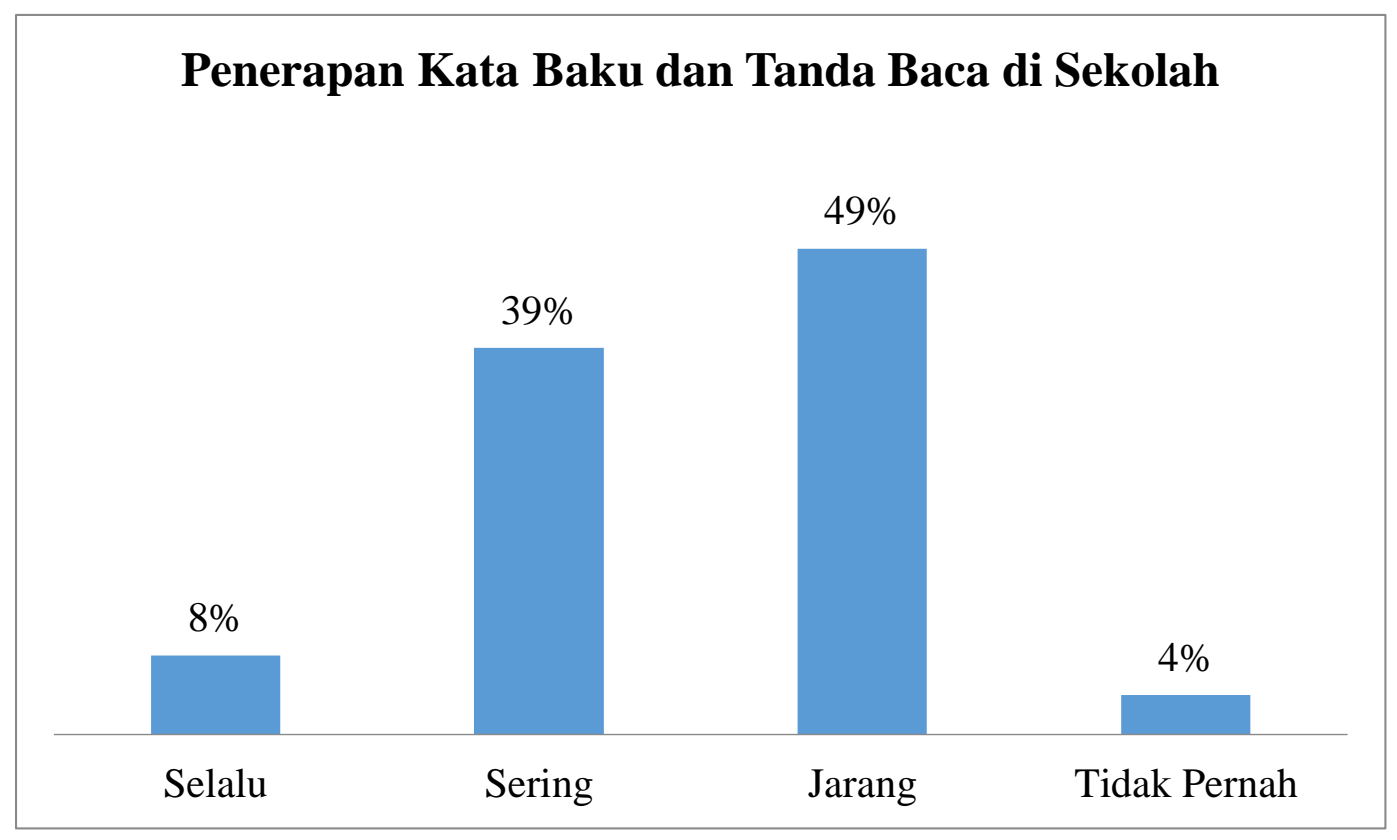

Gambar 1. Hasil Penerapan Kata Baku dan Tanda Baca di Sekolah 
Berdasarkan Gambar 1 menunjukkan bahwa siswa kelas V SD Negeri Pandean Lamper 04 jarang menerapkan kata baku dan tanda baca di sekolah. Jarangnya siswa menerapkan kata baku dan tanda baca di sekolah menyebabkan siswa kurang pengetahuannya tentang kata baku dan tanda baca. Selain itu siswa tidak terbiasa menulis menggunakan kata baku dan tanda baca yang tepat sesuai aturan. Sehingga dalam hasil tulisan siswa banyak kesalahan penerapan kata baku dan tanda baca dalam hasil tulisan siswa.

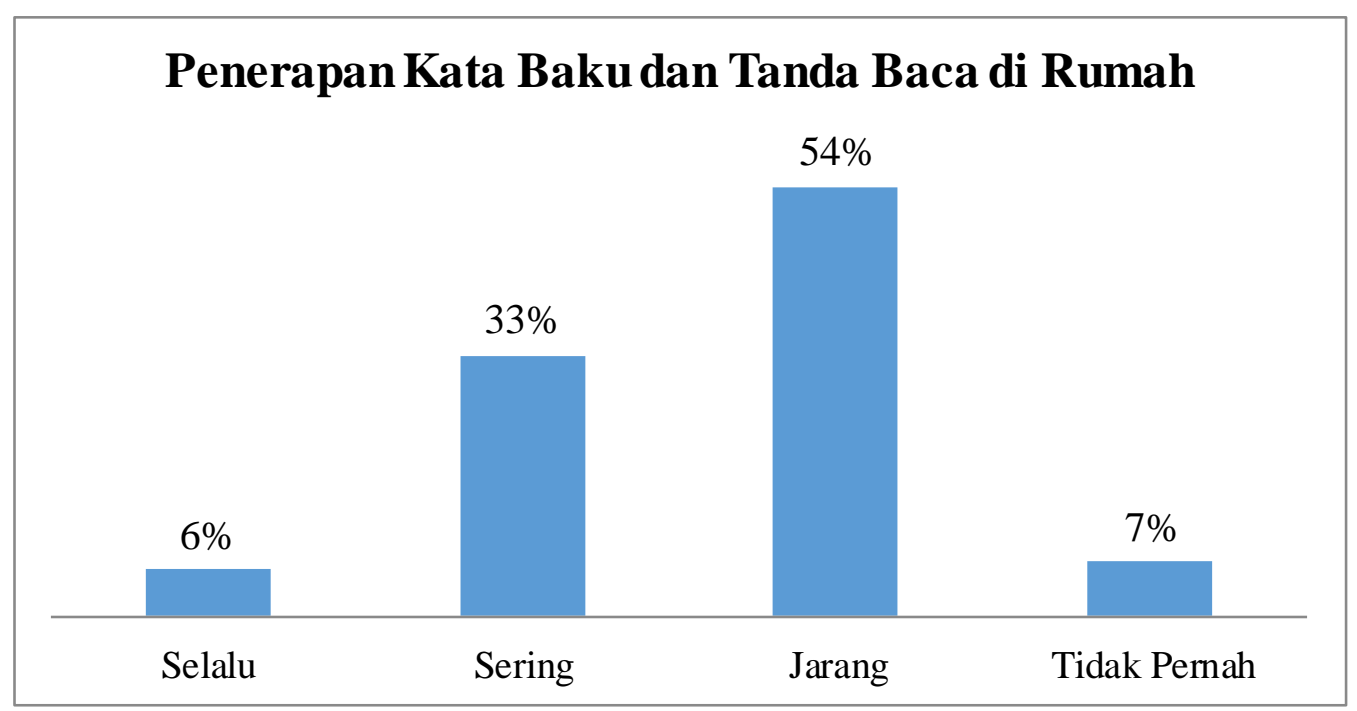

Gambar 2. Hasil Penerapan Kata Baku dan Tanda Baca di Rumah

Berdasarkan Gambar 2 menunjukkan bahwa siswa jarang menerapkan kata baku dan tanda baca di rumah. Jarangnya siswa menerapkan kata baku dan tanda baca di rumah juga menyebabkan kurangnya pengetahuan siswa tentang kata baku dan tanda baca. Selain itu siswa tidak terbiasa menulis tidak menggunakan kata baku dan tanda baca yang sesuai dengan aturan. Sehingga dalam hasil tulisan siswa banyak kesalahan penerapan kata baku dan tanda baca.

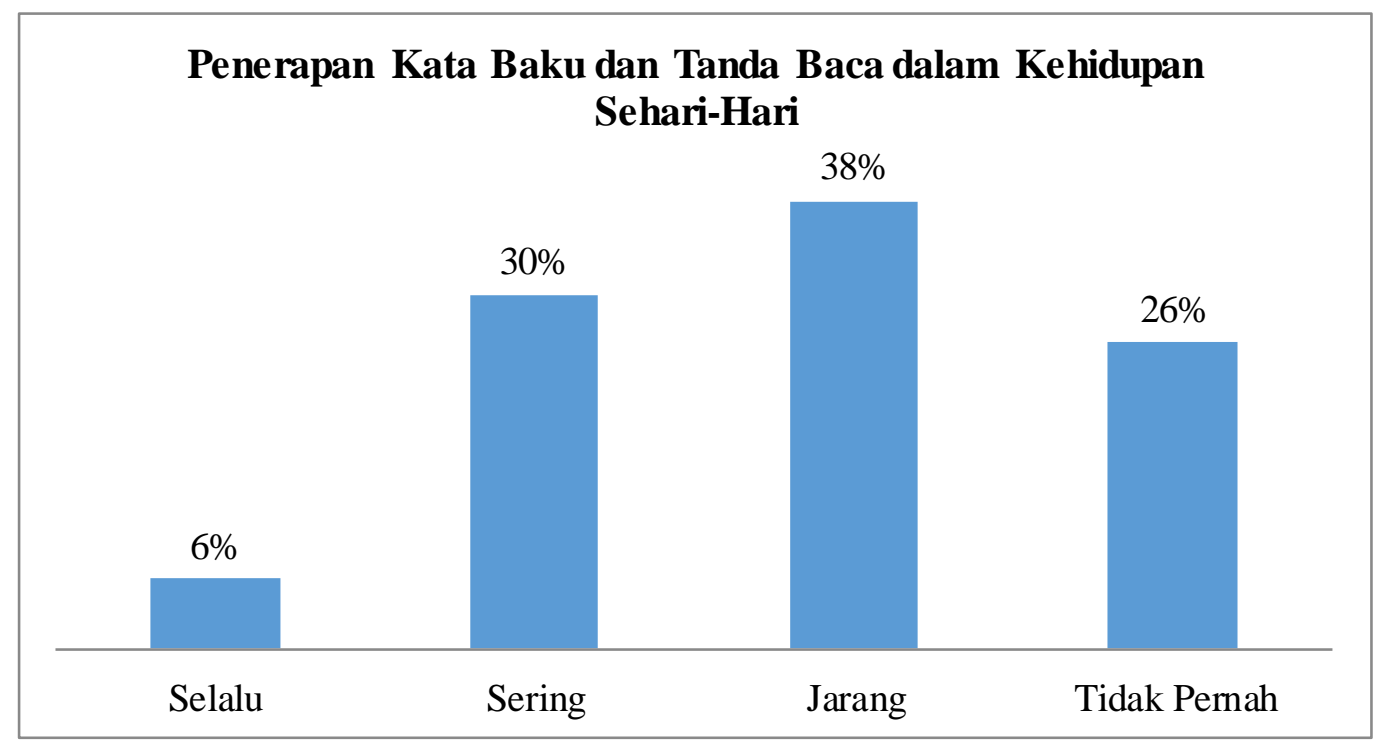

Gambar 3. Hasil Penerapan Kata Baku dan Tanda Baca 
Berdasarkan Gambar 3 menunjukkan bahwa siswa jarang menerapkan kata baku dan tanda baca dalam kehidupan sehari-hari. Jarangnya siswa menerapkan kata baku dan tanda baca dalam kehidupan sehari-hari menyebabkan kurangnya pengetahuan siswa tentang kata baku dan tanda baca. Selain itu siswa tidak terbiasa menulis menggunakan kata baku dan tanda baca yang sesuai aturan. Sehingga dalam hasil tulisan siswa banyak kesalahan penarapan kata baku dan tanda baca.

Berdasarkan hasil wawancara dengan guru kelas V SD Negeri Pandean Lamper 04 dapat disimpulkan bahwa dalam kegiatan menulis tentu siswa mengalami kesulitan. Kesulitan yang dialami siswa tentu berbeda-beda. Secara keseluruhan kesulitan yang dialami siswa yaitu kesulitan merangkai kata-kata yang akan ditulis. Kemudian siswa membutuhkan waktu yang lama saat kegiatan menulis. Dalam hasil tulisan siswa sering ditemukan kesalahan contohnya kesalahan penulisan huruf kapital, kesalahan penulisan tanda baca, dan kesalahan penulisan kata yang seharusnya digabung dan seharusnya dipisah.

Siswa sudah pernah mendapatkan pembelajaran tentang kata baku dan tanda baca di kelas sebelumnya namun hanya dasar-dasar. Kemudian di kelas $\mathrm{V}$ siswa mengembangkan baik dalam menulis maupun berbicara. Akan tetapi, siswa masih kesulitan memahami kata baku dalam menulis maupun berbicara. Tidak hanya siswa yang kesulitan, guru juga kesulitan menerapakan kata baku saat berbicara. Tanpa disadari, guru masih sering menggunakan kata tidak baku saat pembelajaran. Kemudian siswa mendengar dan meniru apa yang diucapkan oleh guru. Selain itu siswa tidak membiasakan berbicara dan menulis menggunakan kata baku. Sedangkan pergaulan dan perkembangan zaman saat ini mempengaruhi bahasa siswa. Siswa lebih mudah mengingat dan lebih senang menggunakan kata-kata gaul.

Setelah melakukan analisis hasil tulisan siswa, hasil angket, dan hasil wawancara, peneliti menemukan banyak kesalahan penerapan kata baku dan tanda baca dalam hasil tulisan siswa kelas V SD Negeri Pandean Lamper 04 Semarang. Melalui hasil angket yang telah diisi siswa dan hasil wawancara dengan guru kelas V SD Negeri Pandean Lamper 04 dapat diketahui bahwa siswa jarang menerapkan kata baku dan tanda baca di sekolah, di rumah, dan dalam kehidupan sehari-hari. Hal tersebut menjadi salah satu faktor yang menyebabkan hasil tulisan siswa banyak ditemukan kesalahan penerapan kata baku dan tanda baca. Siswa jarang menerapkan kata baku dan tanda baca di sekolah, di rumah, dan dalam kehidupan sehari-hari menyebabkan siswa tidak terbiasa menulis menggunakan kata baku dan tanda baca yang benar sesuai aturan.

Berdasarkan penelitian yang dilakukan dapat diketahui siswa menulis tidak menggunakan kata baku dan tanda baca dipengaruhi oleh faktor internal dan eksternal. Faktor internal terdiri dari: (a) kurangnya pengetahuan dan pemahaman siswa tentang kata baku dan tanda baca, (b) kurangnya latihan menulis menggunakan kata baku dan tanda baca, (c) ketidaktelitian siswa, dan (d) rendahnya minat siswa dalam menulis. Faktor eksternal yang memperngaruhi siswa menulis tidak menggunakan kata baku dan tanda baca terdiri dari: (a) kurangnya penguasaan guru tentang kata baku dan tanda baca, (b) lingkungan tempat tinggal dan pergaulan siswa, dan (c) perkembangan teknologi informasi dan komunikasi.

\section{Simpulan dan Saran}

Berdasarkan hasil penelitian kesalahan penerapan kata baku dan tanda baca dalam kembali isi cerita fabel subtema 1 manusia dan lingkungan kelas V SD Negeri Pandean Lamper 04 Semarang pada hasil tulisan siswa banyak ditemukan kesalahan penerapan kata baku sebanyak 233 kesalahan dan kesalahan tanda baca sebanyak 180 kesalahan. Rincian kesalahan tanda baca terdiri dari: (a) kesalahan penerapan tanda titik sebanyak 78 kesalahan, (b) kesalahan penerapan tanda koma sebanyak 41 kesalahan, (c) kesalahan penerapan tanda petik sebanyak 48 kesalahan, (d) kesalahan penerapan tanda hubung sebanyak 6 kesalahan, dan (e) kesalahan penerapan tanda tanya sebanyak 7 kesalahan. Berdasarkan hasil angket yang telah diisi oleh siswa kelas V menunjukkan siswa kelas V SD Negeri Pandean Lamper 04 Semarang jarang menerapkan kata baku dan tanda baca di sekolah, di rumah, dan dalam kehidupan sehari-hari. Hal itu juga sesuai hasil wawancara dengan guru kelas V SD Negeri 
Pandean Lamper 04, siswa sulit sekali menerapkan kata baku dan tanda baca saat menulis dan berbicara. Siswa menulis tidak menggunakan kata baku dan tanda baca dipengaruhi oleh faktor internal dan eksternal. Faktor internal terdiri dari: (a) kurangnya pengetahuan dan pemahaman siswa tentang kata baku dan tanda baca, (b) kurangnya latihan menulis menggunakan kata baku dan tanda baca, (c) ketidaktelitian siswa, dan (d) rendahnya minat siswa dalam menulis. Faktor eksternal yang memperngaruhi siswa menulis tidak menggunakan kata baku dan tanda baca terdiri dari: (a) kurangnya penguasaan guru tentang kata baku dan tanda baca, (b) lingkungan tempat tinggal dan pergaulan siswa, dan (c) perkembangan teknologi informasi dan komunikasi.

Saran untuk guru hendaknya melatih dan membiasakan siswa menulis menggunakan kata baku dan tanda baca yang benar sesuai aturan. Guru hendaknya lebih sering meminta siswa untuk membaca baik di sekolah maupun di rumah. Saran untuk siswa seharusnya memiliki buku pedoman ejaan bahasa Indonesia. Siswa seharusnya berlatih dan membiasakan menulis menggunakan kata baku dan tanda baca yang benar.

\section{Daftar Pustaka}

Arifah, Fita Nur dan Isnawati Nur. 2016. Pedoman Kata Baku dan Tidak Baku. Yogyakarta: Araska

Balai Pendidikan dan Pelatihan Keagamaan Padang. 2019. Pembelajaran Bahasa Indonesia dalam Kurikulum 2013: Sebuah Kajian dalam Mata Diklat Penerapan Kurikulum 2013. https://bdkpadang.kemenag.go.id/index.php?option=com_content\&view=article\&id=674: agusridadsember\&catid=41:topheadlines\&ltemid=158 (Diunduh 3 Maret 2019).

Cahyani, Isah dan Hodijah. 2007. Kemampuan Berbahasa Indonesia di Sekolah Dasar. Cetakan ke-1. Bandung: UPI Press.

Chaer, Abdul. 2011. Tata Bahasa Praktis Bahasa Indonesia. Jakarta: Rineka Cipta

Dalman. 2018. Keterampilan Menulis. Cetakan ke-6. Depok: PT RajaGrafindo Persada.

Kamus Besar Bahasa Indonesia Edisi Kelima. 2017. Jakarta: Badan Pengembangan dan Pembinaan Bahasa Kementerian Pendidikan dan Kebudayaan.

Khodijah, Siti. 2017. "Analisis Kesalahan Huruf Kapital dan Tanda Baca Pada Paragraf Deskriptif Siswa Kelas V MI Nurul Islam Grogol Depok”. Skripsi Fakultas Ilmu Tarbiyah dan Keguruan UIN Syarif Hidayatullah. (online), (http://repository.uinjkt.ac.id/dspace/bitstream/123456789/36247/1/Siti\%20KhodijahFITK diakses pada tanggal 29 Maret 2019)

Kosasih dan Hermawan. 2012. Bahasa Indonesia Berbasis Kepenulisan Karya IImiah dan Jurnal. Bandung: CV. Thursina

Kusumaningsih, Dewi. 2013. Terampil Berbahasa Indonesia. Yogyakarta: CV Andi Offset. 
Moleong, Lexy. 2002. Metodologi Penelitian Kualitatif. Cetakan ke-17. Bandung: PT Remaja Rosdakarya.

Nurmalisa, Dina. 2010. Keterampilan Menulis Kembali Dongeng dengan Teknik Bola Panas. Pena Jurnal IImu Pengetahuan dan Teknologi. (online) (https://jurnal.unikal.ac.id/index.php/pena/article/view/19 diakses pada tanggal 5 April 2019)

Nurgiyantoro, Burhan. 2010. Sastra Anak Pengantar Pemahaman Dunia Anak. Cetakan ke-2. Yogyakarta: Gadjah Mada University Press.

Peraturan Menteri Pendidikan dan Kebudayaan Nomor 67 Tahun 2013

Rajab, IImia. 2017. "Analisis Penggunaan Tanda Baca Dalam Menulis Teks Laporan Hasil Observasi Siswa Kelas X SMA Negeri 1 Pangkajene Kabupaten Pangkep". Skripsi. Fakultas Bahasa dan Sastra Universitas Negeri Makassar. (online), (http://eprints.unm.ac.id/5976/1/SKRIPSI\%20ILMIA\%20RAJAB.pdf. Diakses pada tangga 26 Maret 2019).

Resmini, Novi dan Dadan Juanda. 2007. Pendidikan Bahasa dan Sastra Indonesia di Kelas Tinggi. Cetakan ke-1. Bandung: UPI Press.

Rosdiana, Yusi. 2008. Bahasa dan Sastra Indonesia di SD. Cetakan ke-3. Jakarta: Universitas Terbuka.

Santosa, Puji. 2011. Materi dan Pembelajaran Bahasa Indonesia SD. Cetakan ke-17. Jakarta: Universitas Terbuka.

Sugiyono. 2015. Memahami Penelitian Kualitatif. Cetakan ke-12. Bandung: Alfabeta.

Sugiyono. 2016. Metode Penelitian Pendidikan Pendekatan Kuantitatif, Kualitatif, dan R\&D. Cetakan ke-23. Bandung: Alfabeta.

Suyitno dan Ngatmini. 2018. Pengantar Praktis Bahasa Indonesia. Cetakan ke-2. Yogyakarta: Magnum Pustaka Utama.

Undang-Undang Nomor 20 Tahun 2003 Tentang Sistem Pendidikan Nasional. 